\title{
Speculation and Social Progress: Financial and Narrative Bubbles in Charles Lever's Davenport Dunn
}

\author{
Silvana Colella \\ University of Macerata, Italy
}

Copyright (c) 2019 by Silvana Colella. This text may be archived and redistributed both in electronic form and in hard copy, provided that the author and journal are properly cited and no fee is charged for access.

\begin{abstract}
Victorian novels of finance have garnered much critical attention in recent years. Yet Lever's Davenport Dunn (1859) has been largely overlooked. This essay investigates Lever's imaginative engagement with finance capitalism, casting new light on his unique take on the appeal of speculation in an Irish context. Set both on the Continent and in Ireland, Davenport Dunn deviates significantly from the standardised tales of financial felony that circulated widely in Victorian print culture. Attending closely to the novel's formal features and narrative strategies, this essay argues that the logic of financial speculation is internalised on the formal level. The novel accords a degree of legitimacy to financial speculation by multiplying lines of divisions between gambling and speculation and by shifting attention to the role of a female character, who stands to win from her commitment to speculative schemes. Notable for its realistic particularity, Lever's representation of the Irish speculator and his entourage probes the limits of moralistic understandings of finance in ways that have hitherto been unacknowledged.
\end{abstract}

Key Words. Charles Lever, Davenport Dunn, Financial Speculation, Social Progress, Gambling, Realism, Women and Business.

Resumen. Las novelas victorianas que tratan el mundo de las finanzas han recibido considerable atención de la crítica en épocas recientes. Sin embargo, Davenport Dunn (1859), de Charles Lever, no ha sido estudiada lo suficiente. En este ensayo se investiga cómo Lever indagó de forma imaginativa en el capitalismo financiero y se analiza su peculiar enfoque, especialmente en lo relacionado con el atractivo que suponía la especulación en el contexto irlandés. La novela está situada tanto en el continente como en Irlanda, y se distancia notablemente de las historias similares sobre fraudes monetarios en las publicaciones victorianas de la época. Partiendo de un análisis detallado de las características formales de la novela, así como de sus estrategias narrativas, en este trabajo se quiere demostrar que la lógica inherente a la especulación financiera tiene una correspondencia en el nivel formal del texto. La novela de alguna forma parece legitimar la especulación financiera mediante la multiplicación de las líneas divisorias entre el juego y la especulación. También produce este 
mismo efecto al centrar el foco de la acción en un personaje femenino, el cual tiene todas las de ganar debido al empeño puesto en determinadas iniciativas especuladoras. Además de aportar minuciosas descripciones realistas, la novela destaca por la representación del especulador irlandés y su entorno, al tiempo que el autor cuestiona los límites morales de las finanzas por medio de elementos narrativos que nunca se han detallado en profundidad.

Palabras clave. Charles Lever, Davenport Dunn, especulación financiera, progreso social, juego, realismo, mujeres y negocios.

\section{Introduction}

In mid-nineteenth-century novels, financial speculation tends to be narrated through a recurrent set of motifs: grand speculative schemes are never successful, fraud always lurks in the background, speculators eventually commit suicide or just die, and their hybris is systematically expunged from the story world. Moreover, satire and sarcasm are often recruited to reinforce the moral of the story, as Dickens does in Little Dorrit (1855-57) and Trollope in The Way We Live Now (1874). For all its associations with uncertainty, volatility and complexity, in the realm of fiction financial speculation is also a dependable generator of predictable plots and narrative certainties: the bubble will burst, the fraud will be exposed, and the cruel optimism of speculative dreams will be revealed as illusory.

That this moralising tale was perceived as hackneyed by the late $1850 \mathrm{~s}$ is attested by the critical reception of Davenport Dunn: "The main villain is a combination of all the recent notorious financial cheats. He is an Irish amplification of Redpath, Sadleir, Colonel Waugh, and half a dozen others. There is nothing very original in selecting such a subject, and all the merit is in the handling" ("Davenport Dunn" 505). The Saturday Review identified various features that distinguished Lever's treatment of the speculator from other contemporaneous accounts: the "local colouring" added to the picture by the author's choice to include Dunn's father in the cast of characters; the quality of Lever's realism ("Lever knows that it is not only the great results, but the furniture, the daily decoration, of success that strikes the reader" 505); and the lack of "sermonising" which the Saturday seemed particularly keen to praise: "there is very little morality in Davenport Dunn and still less sentimentalism. The moral of the tale simply consists in giving us vaguely to understand that the adventures of the two adventurers are of the wrong sort. In a general kind of way, speculation is discountenanced" (506). All in all, Davenport Dunn pleased Victorian reviewers for the ways in which Lever solicited new interest around a subject deemed unoriginal. ${ }^{1}$

If Victorian reviewers were favourably impressed with Lever's Irish novel of finance, twentieth-century critics have manifested little interest in this text. Recent assessments of his oeuvre - the essays collected in Charles Lever: New Evaluations (1991) and Haddelsey's Charles Lever: The Lost Victorian (2000) - do not even mention the novel en passant, while according much attention to Lever's serious fiction, Lord Kilgobbin (1870) in particular. When Davenport Dunn is mentioned, it is either summarily liquidated in a couple of lines (Reed 184) or presented, in a short paragraph, as a dramatisation of the Irish Question within the paradigm of stock-market fiction (Wagner 135). ${ }^{2}$ Likewise, in recent histories of the Irish novel - Murphy's Irish Novelists and the Victorian Age (2011) and Hand's History of the Irish Novel (2011) - the adventures of Lever's speculator fail to attract any degree of attention. Yet, as Victorian reviewers duly noted, not only is Davenport Dunn better crafted than Lever's previous attempts at writing non-comic novels, it is also in some ways 
innovative with respect to the narrative of financial speculation (and scandals) then prevailing.

This essay investigates Lever's imaginative engagement with finance capitalism, casting new light on his unique take on the appeal of speculation in the economic climate of post-Famine Ireland. Davenport Dunn deviates from the standardised tale of financial felony in ways that have been hitherto unacknowledged. These deviations can be detected in the story proper as well as on the formal level. First, I consider how this novel positions the role of speculation in relation to social progress, experienced by characters in terms of inclusion and individualisation (or the lack thereof), focusing on the non-marginal role played by female economic agency. Secondly, I take a closer look at the novel's formal structure, characterised by the alternation of realist and picaresque narrative modes, claiming that the logic of financial speculation is internalised on the level of form. Like other novels of finance, Davenport Dunn warns readers against the risks and ruses of speculative schemes. Yet it also contributes to naturalising speculation as more rational than gambling, by aligning it with narrative order and linearity as well as with a distinctly bourgeois work ethic. As historians and sociologists claim, financial markets gained increased legitimacy over the course of the nineteenth century. A crucial strategy in this process of normalisation consisted in policing the boundaries of finance, by framing gambling as its irrational "other". ${ }^{3}$ In Davenport Dunn, several lines of distinctions are drawn (geographical, formal and metaphoric) between speculation and gambling. Thus, I conclude, the novel participates in the "normalization of "wild contingency" (Stähli 42) even as it replicates the narrative of deception and fraud so frequently encountered in the pages of Victorian novels and the periodical press. As McCourt rightly notices, Lever's later novels, "are infinitely more innovative and experimentary than the earlier work by this writer who never stopped attempting to reconfigure his country in fiction" (157). Habitually disregarded by critics as a 'minor' contribution, Davenport Dunn should rather be viewed as a bold experiment in the art of narrating finance at a time when the financial world, beset by irregularities, was the subject of intense public scrutiny.

\section{Dunn's social progress}

In his book Progress: A Reconstruction (2016), Peter Wagner identifies four dimensions of progress: epistemic, economic, social and political. Over the course of the eighteenth and nineteenth centuries, he argues, these dimensions did not develop along the same timeline. Progress of knowledge, for instance, predated economic progress, and the latter did not overlap with social and political progress. Wagner defines "social progress" as "the creation of conditions amenable to personal self-realization" (56). While it is habitual to consider freedom and equality as appropriate measures of social progress, Wagner argues that the twin categories of "individualization" and "inclusion" should also be taken into account as the "phenomena through which freedom and equality present themselves experientially" (63). It is important to underline, Wagner concludes, that struggles against formal domination, which have led to social progress, "have predominantly been struggles for equal inclusion and recognition, against exclusion and misrecognition, not against commodification, rationalization, or abstraction" (82) as Marx, Weber and Adorno would have it.

In the social imaginary of Lever's novel, the world is sharply divided between those who are "included" or entitled by birth, and the "excluded", scrambling for a seat at the table. As one character, the inveterate gambler, Grog Davies, observes in a moment of extreme bitterness: "the fellows that are born to a good station and a good property are all fair and honest, if they like it; the rest of the world must be rogues, whether they like it or not" (II 91). Lever represents economic progress in Ireland as an unstoppable onward march, a selfpropelled force of history. The chapter entitled "The World's Changes" traces the rapid 
transformations effected by the spirit of industry, "a spirit which hitherto had been unknown to Ireland" (I 56), comparing them to a process of re-colonisation: "It was like re-colonizing an empire, so subversive were all the innovations of what had preceded them" (I 56). More specifically, this chapter alludes to what James O'Shea calls the "mini-revolution in land ownership" (98) brought about by the Encumbered Estates Act (1848-9) and its subsidiary bills, which had facilitated John Sadleir's rapid and infamous career. Dunn's professional success is linked to the transformations prompted by the new legislation, which he shrewdly exploits to his own advantage. ${ }^{4}$ Focusing on a specific moment of post-Famine history, when a sizable proportion of the land acreage changed hands (Kelly), paving the way for the rise of "a set of spurious gentry" (I 58), Lever depicts Irish modernity mostly in terms of economic progress, as perceived by an ambitious man of business whose "associations", "companies" and "industrial speculations" (I 55) seem to know no bounds.

In contrast to this dynamism, Lever's vision of the social structure emphasises fixity and lack of progress. ${ }^{5}$ The aristocratic grandees - Lord Lackington and his wife, Lord Glengariff and his daughter, among others - hoping to profit from this economic revolution, hold on defensively to their strict paradigms of social exclusion: "These men are signs of the times", Lord Lackington explains to his peers, referring to Dunn's success, "emblems of an era; just like the cholera, the electric telegraph, or the gold-fields of Australia. We must not accept them as normal, do you perceive? They are abnormal incidents of our age" (I 82). This sweeping critique of speculation is firmly associated with the self-protective perspective of aristocratic characters whose hypocrisy the novel gleefully exposes: they shun the self-made financier but not his services.

Lever devotes much attention to how the excluded, the outsiders, attempt to work their way up, by lawful and unlawful means. ${ }^{6}$ Both the financier, Dunn, and the gambler, Davies, are outsiders, but while the latter - "who for thirty-odd years had been a 'leg' and a swindler" (I 129) - schemes and plots in order to facilitate his daughter's ascension to higher spheres, the speculator is himself a figure of economic inclusion. Unlike Dickens and Trollope, Lever does not envelop the financier in a thick halo of mystery. ${ }^{7}$ Not only are Dunn's origins well known (he is the son of a shopkeeper), but his caring and affectionate relationship with his father, illustrated in various episodes throughout the novel, confers upon the narrative of his social progress a sentimental quality. Dunn is never allowed to forget the distance he has travelled, nor the slights and rejections he has experienced in the past. His evolution from outcast to celebrated "man of the people" is punctuated with reflections on his past. "Most men who have attained to high station from small beginnings", observes the narrator, "flung the past behind them... Not so Davenport Dunn" (I 88). The Irish financier is haunted by memories of exclusion, with their attendant feelings of shame and social resentment, which hold a tenacious grip on his conscience, even as he reaches the apex of success: "Certain incidents of his life never left him; there they were as if photographed on his heart...Like avenging spirits, these memories travelled with him whenever he journeyed" (I 88).

Lever constructs Dunn's trajectory as one of precarious social inclusion and individualisation - precarious because the welcome (grudgingly) extended to him by the Anglo-Irish Aristocracy and the English ruling class is blatantly self-interested and because his self-fashioning, buttressed by the wealth he has accumulated, is destabilised by frequent returns of his troubled past. Successful though Dunn is, the power and influence he is able to wield in Ireland and England are never sufficient to wipe out the story of exclusion he seems unable to outgrow. Lever's perspective emphasises the magnitude of Dunn's economic and political sway in terms that oscillate between admiration and sarcasm. ${ }^{8}$ Readers are offered detailed descriptions of Dunn's enterprises and the many fields in which he plays his financial game. With uncharacteristic realism, this novel of finance provides specificity in lieu of mystery, and does so by repeatedly portraying the financier at work. Yet, it is the residue of 
outsiderness that Lever is most interested in bringing to the fore - not the vulgarity of the parvenu who accumulates economic capital and strives to translate it into social prestige, but the obsessions and fears of the excluded, unable to forget. Dunn's upward mobility story, in other words, is not just measured in ostensibly moral terms against standards of honesty and fair dealing; it is also measured in social terms against enduring standards of inclusion and exclusion that not even the subversive revolution of industrial progress has dented. Of course, this novel too ends up confirming that the speculator is a cheat and as such morally reprehensible. But what makes him stand out, as a fictional version of real-life notorious paragons of financial felony, is Dunn's almost paradoxical position as an insider, at the very centre of things, who continues to see himself as an outsider impelled by his own conscience to revisit, at regular intervals, the scenes of exclusion that shaped his self-understanding. This focus on Dunn's self-perception is how the novel registers the distance between economic progress and social progress, in the Irish context. The former is or appears unstoppable, while the latter is lagging far behind.

In Dunn's upward mobility story much emphasis is placed on self-determination in conjunction with plotting and scheming. But the element that Bruce Robbins identifies as an indispensible ingredient of upward mobility stories - a benefactor's helping hand - is absent. While no character plays the part of the "patron, mentor, or benefactor" (Robbins xv) in Lever's novel, financial markets, and the opportunities they open up for unscrupulous overreachers, seem to provide the closest equivalent to an anonymous benefactor. This is not to imply that Lever associates financial markets with the common good. Rather, his fiction offers two versions of the upward mobility story, differentiated along gender lines. Dunn's trajectory is propelled forward by a mixture of self-determination, conniving and hard work, from which any notion of the common good has been expunged or reduced to the status of a lie. In Sybella's story, on the other hand, self-reliance, risk-taking and business acumen are tentatively aligned with the common good, as I argue in the next section. Playing the role of Dunn's assistant, Sybella takes an active interest in land speculation, which she attempts to reorient in the direction of societal benefits, eventually reaping substantial rewards (love and wealth). That Lever should devote much narrative attention to female agency in relation to speculative schemes is further evidence of his unconventional take on the impact of finance capitalism.

\section{Sybella's Calculations}

In Davenport Dunn leisure is a privilege of birth. Despite his immense wealth, Dunn hardly enjoys any respite from work. Lever accords him the bourgeois prestige of a stern work ethic: he is up at five and by dinnertime his daily work is still unfinished. Dunn's ability to endure long hours of arduous toil, while dealing with the pressing demands of potential investors, is praised even by his detractors: "he goes through the work of ten men every day of his life" (I 40), says Mr Kellett, one of his most vocal antagonists. And because readers actually see Dunn at work, nearly every time he appears on stage, the income derived from these multiple activities could legitimately be perceived as rightly earned, more so than the inherited income of the various rentiers (Lords, Dukes, Earls and such likes) the novel parades. Having built a complex financial empire, comprising several companies, a joint-stock bank, and various land development projects, Dunn and his secretary have time for little else. It is remarkable how often the narrator itemises what Dunn is doing, whether it is meeting with clients (I 174), sending out important dispatches or receiving them (I 425-27), going through a monumental mass of correspondence, networking with politicians (II 213-24) or appeasing journalists. As his surname suggests, Dunn is a hard-working personage who gets things "done". 
To cope with this amount of business, he avails himself of the services of Hankes, his shady factotum, and the skills and ingenuity of Sybella Kellett, daughter of a proud and impecunious Captain, whose heavily mortgaged property goes under the hammer in the Encumbered Estates' Court at the behest of Dunn. This sale leaves father and daughter in a vulnerable position. While the Captain, peevish and resentful, conveniently dies, Sybella accepts Dunn's offer to become the companion of Lady Augusta, daughter of Lord Glengariff whose estate, located in a remote and picturesque corner of Ireland, is about to be radically transformed into a magnificent "watering-place", through the magic of speculation: "The Grand Glengariff Villa Allotment and Marine Residence Company", the narrator informs us, "was a splendid scheme, whose shares were eagerly sought after at a high premium" (II 151). A long-time admirer of "hardy men of enterprise and daring who had pushed their fortunes in far-away lands" (I 68), Sybella is not fit to be just a companion. Rather, she turns both her idealism and her practical business skills to good use, serving as company promoter, assistant, mediator and much else for the Grand Glengariff scheme. The role she plays in relation to Dunn and what she gains from her involvement in financial speculation are worthy of a closer look, as her social progress is decidedly more triumphant, at the end of the story, than Dunn's.

Scholars have discussed "the gradual assumption of authority by the female characters" in Lever's novels (Bareham, "Outsider" 109): when he ceases to write novels about military high life, Lever "moves towards a series of stories where, without the control, wisdom and maturity of the females, the world would collapse" (102). In Davenport Dunn, Sybella's assumption of authority is contingent on her embracing of speculation: she voices her enthusiasm for the advent of industrial modernity in Ireland in eloquent terms; takes an active part in its implementation, and, upon discovering that the dream of prosperity for all is a lie, concocts a clever plan that will outsmart the speculator's best-laid schemes. There seems to be almost no limit to what this intrepid female character is able to achieve. ${ }^{9}$ In return for her heroic exertions, Sybella gains wealth, love and inclusion in the upper spheres of society. Her story is one of unhampered social progress, facilitated by her open-minded attitude towards speculation and change.

Like other young female characters in Victorian fiction, Sybella has a vivid imagination nurtured by the adventurous stories she likes to read - an imagination that seemed destined to collide with the harsh realities of impoverishment and lack of opportunities. Instead, she becomes the resourceful heroine in a story that provides more than one opportunity for self-realisation. Once installed at Glengariff, Sybella soon makes herself indispensable. In a few weeks, notes the narrator,

Not only had she addressed herself to the task of an immense correspondence, but she had drawn out reports, arranged prospectuses, and entered into most complicated financial details with a degree of clearness that elicited marked compliment from the different bodies with whom this intercourse was maintained. The Glengariff Joint Stock Company, with its half-million capital, figured largely in the public journals...Her interest once excited, Sybella Kellett's zeal was untiring. Already she anticipated the time when the population of that poor village - now barely subsisting in direst poverty - should become thriving and happy. (I 370)

Her business acumen, shrewdly spotted by Dunn, ${ }^{10}$ makes her a trustworthy interlocutor; her imagination, in the service of company promotion and advertising, proves a valuable asset, while her "knowledge of the people" (II 155) allows Sybella to mediate between buyers and sellers in a most competent way. In other words, the woman of business, who believes in commercial heroism, lends legitimacy to speculative enterprises that might otherwise appear suspicious and volatile. More to the point, Sybella engages in specific market transactions, 
positioning herself as the rational arbiter of economic value: "It was her rule never to engage in any purchase when she had not herself made a visit to the spot in question, ascertained in person all its advantages and disadvantages, and speculated how far its future value should influence its present price" (II 158). Sybella's speculations on future values are nothing if not rational and honest calculations, based on her first-hand knowledge of the people and the properties she insists on surveying personally, though they are located "in strange out-of-theway places no map had ever indicated" (II 158).

When Lever describes her tasks, never once reverting to ironic commentary, speculation appears aligned with rationality, the powers of observation, knowledge of the market, and expert predictions - in short all the features that in the "kaleidoscope of finance" distinguish 'good' from 'bad' speculation. ${ }^{11}$ That Sybella is also committed to stipulating fair bargains, respectful of the rights of peasants, adds a compassionate twist to her negotiating skills and makes it "well-nigh impossible to conclude any bargain for land without her cooperation" (II 157). She knows her clients well and has won their trust. The same chapter in which Sybella's rational calculations are shown to be the pivot around which the Glengariff scheme turns, also contains bemused narratorial observations about the arbitrary lottery of land speculation:

Spots of ground the least attractive, tenements occupying the most ill-chosen sites, ugly and misshapen remains of cottages long deserted, were all vaunted as fully as good or better than their neighbours had sold for thousands. It must be owned, the market price of any article seemed the veriest lottery imaginable. (II, 154)

The narrator first exposes the inflated claims of "the imaginative literature of speculation" (II 151 ) - the puffed-up descriptions of financial projects "patronized by our betters" - and then details how Sybella's negotiations stabilise prices and determine values according to procedures that are neither arbitrary nor inexplicable. The novel, in other words, projects two contrasting views of financial speculation: as an unfathomable lottery, on the one hand, and as a process of value creation, based on rational calculations, on the other. While the narrator lampoons the lottery of speculation as one further illustration of the cultural hegemony of the aristocracy, ${ }^{12}$ Sybella's speculations about future values are presented in admiring terms as efficient and just. Of course, driving prices up, as she does in order to protect the interests of the poorest in the land, does not meet with Dunn's approval. But so long as potential sellers refuse to bargain with anyone else, Sybella remains in charge.

The tension between condemning speculation for its inflated claims and exploring its mechanisms is palpable throughout the novel. Lever's inquisitive attitude (how are prices fixed and future values predicted?) drives the financial plot into territories that other novelists did not chart: the role Sybella plays is a telling case in point. Through her intercessions, speculation is represented as an instrument for change (both individual and collective), which could be used judiciously. By abstaining from ironic or sarcastic commentary about Sybella's performance, Lever encourages his readers to entertain the idea that finance may not be an intrinsically vicious development of modern capitalism, nor an abstract mystery. Since Sybella is the moral centre of the novel, her ratification of speculative practices carries significant symbolic weight, which will not be entirely disavowed even when the story veers towards the conventional and Dunn is exposed as a rogue and a swindler. He is to be blamed, of course, and Sybella will be the first, among his collaborators, to turn against him. But by diversifying the usual scenario of financiers and their acolytes with the inclusion of a female figure who actively promotes speculative schemes, by adding particulars to the universal story of financial scandal, Lever keeps more than one option open: moral condemnation of the 
individual overreacher, Dunn, is one possibility, approval of Sybella's vision of speculation is another.

This approval is signalled most clearly by a twist in the plot that ensures for Sybella a future of prosperity. Running parallel to Dunn's story of rise and fall is a sub-plot involving the disputed legitimacy of Lord Lackington's estate and title. The document that will prove his illegitimacy and install Conway, a soldier in the Crimea, as the rightful heir is found by Sybella in one of those far-away cottages that she is in the habit of surveying in order to ascertain their future value. Trusting her instincts, Sybella buys this cottage for herself, keeps hold of the ancient documents stored therein (much sought after by Hankes and Dunn, on behalf of Lackington) and, when the right time comes, produces the incontrovertible proof that Conway's claim to the estate and title is legitimate.

This fortunate purchase is preceded by an emblematic scene in which Sybella embarks upon a risky journey through inhospitable and dangerous mountainous landscapes in order to reach the cottage. Hankes insists on accompanying her, only to discover that he cannot keep up with Sybella's pace. Petrified by the perils of the journey, he turns his horse round and makes for home. This scene is emblematic of the novel's take on risk: "without danger there is no greatness", Sybella claims, "in the hazardous conflicts where life is ventured, high qualities only are developed" (II 181). Compared to Hankes's pusillanimity, Sybella's intrepid welcoming of hazards qualifies her as a most fearless risk-taker. She has the right predisposition to understand the logic of financial speculation and to benefit from it. Investing all her savings in the purchase of the cottage, "by tradition said to have once been inhabited by the poet Spenser" (II 184), risking her money to buy an apparently worthless spot, Sybella indirectly secures for herself a very comfortable future. Taking risks pays off in this novel, at least for its gallant heroine. After a brief stint in the Crimea, which corroborates her love of risk, Sybella marries Conway who has rightfully come into possession of a large estate and a title. In the parable of this rather atypical female character, involvement with speculative schemes leads to social progress: both Sybella's practical expertise in business and her risktaking propensities are instrumental in ensuring success. She obtains the most coveted prizes in this novel, rank and wealth, though she does not intentionally set out to gain them.

Considering how much narrative space Lever devotes to tracing Sybella's actions, one could argue that the typical story of financial roguery, which the novel reproduces, is the pretext to explore alternative routes, untrodden narrative paths that allow Lever to probe the received wisdom of anti-speculative perspectives. Instead of placing women as innocent victims of unscrupulous financiers, ${ }^{13}$ Lever pushes the boundaries of plausibility to create a story that, while warning readers against the risks of speculation, also illustrates how a female risk-taker, of uncommon abilities, manages to outsmart the speculator at his own game. Of course, on the level of narrative commentary and explanation, much attention is accorded to drawing the usual distinctions between commercial dishonesty and the chivalry and heroism displayed on the Crimean battlefields (II 423), or between the insane "money-getting passion" of a whole nation and the right values of a few selected individuals, Sybella in primis. Nonetheless, as the Saturday Review was quick to notice, speculation is "discountenanced" in this novel only "in a general kind of way" ('Davenport Dunn 506). The particulars Lever adds to the general make all the difference.

\section{Narrative Bubbles: Gambling and Speculation}

Davenport Dunn is a multiplot novel with an extensive geographical reach. Its settings include Ireland, England, Italy, France, Belgium, and Germany. The number of chapters set in Ireland is almost equal to those set on the Continent, which makes this text a hybrid European-Irish tale. ${ }^{14}$ Looking at the distribution of scenes and episodes on the novel's map 
(what happens where and to whom), one consistent pattern stands out. Dunn makes one short appearance in Italy, at the onset of the story, but the speculation plot unfolds entirely in Ireland except for a couple of scenes set in London. Despite his vast network of international business contacts, Dunn is no cosmopolitan capitalist: "I'm always more at my ease", he claims, "when I know the geography of the land I live in" (I 110). Conversely, the gambler, Grog Davies, operates mostly from continental locations; the plot strand revolving around his schemes advances, in a meandering way, as this notorious blackleg travels from one foreign country to the next to avoid capture and secure his goals.

One immediate effect of this geographical distribution of episodes is to create a neat distinction between the gambler and the speculator, who inhabit different spaces and whose paths never cross, except for a brief, inconsequential scene before the final sensationalistic episode, staged in a train carriage, in which Davies murders Dunn. Geography, I would argue, performs significant ideological work in this novel: the physical separation of Dunn and Davies, who have much in common as both are magisterial schemers, facilitates the representation of speculation and gambling as two different activities, each with its own sphere of influence. It is certainly meaningful that Lever chooses to integrate gambling in a story of speculation, as if to acknowledge contemporaneous debates about their similarities. ${ }^{15}$ Even more significant, however, is that the novel takes position vis-à-vis these debates by reinforcing the notion that gambling and speculation can be disconnected, and by placing the latter more squarely on the side of the rational.

What produces this effect is not just the geographical distribution of episodes. The narrative modes Lever deploys also contribute to sharpening differences. The picaresque, episodic, desultory story line pivoting on Grog Davies, and the more straightforward, orderly, even predictable trajectory of Dunn's career are marked by formal disparities. The chapters set on the Continent are reminiscent of eighteenth-century picaresque models: chance encounters abound, new characters are often introduced who have little bearing on the main plot, and implausible coincidences facilitate the generation of new incidents. ${ }^{16}$ Grog Davies easily transitions from sitting in an opera house, enjoying the show with his daughter, to committing a murder, in the space of a few paragraphs; he is forever plotting and scheming and therefore alert to the tiniest atom of luck thrown his way by sheer chance, which sends his story spinning in various directions. Lever's earlier novels of rollicking fun, the novels that made him famous in the 1840s, had a similar structure, "connecting amusing incidents by a light thread of narrative" ("Davenport Dunn" 228). Amusement is indeed a quality of Grog's picaresque adventures, much appreciated by Victorian reviewers who compared Lever's style to Smollet's.

But when attention shifts to Dunn, Sybella and the restricted cast of characters featured in the speculation plot, the mode of serious realism tends to prevail. More instructive than amusing, this plot follows a linear trajectory, episodes and scenes are more orderly strung together, narratorial asides take on a quasi-journalistic tone, digressions are kept to a minimum and when they are included the narrator always makes sure to justify their presence. In other words, speculation is aligned with narrative control and order, just as gambling is associated with the meandering movements, digressions and improbabilities of a plot irreverent of boundaries. For instance, the narrator is impelled to apologise with the reader quite frequently when recounting Grog Davies's exploits: "perhaps our reader might not have patience with us were we to follow Davies through all the devious turns and windings of this tortuous discourse" (II 118), he remarks at one point. "We, perhaps, owe an apology to our reader for inverting in our narrative the actual order of these events" (II 70), notes again the narrator before introducing a lengthy digression about Davies writing a note. The metaphor of the writer as "huntsman", chasing his own creations, sums up quite neatly the sense of disorder or uncertainty evoked in the gambling plot: 
If it be wearisome to the reader to have his attention suddenly drawn from the topic before him, and his interest solicited for those he has well-nigh forgotten, let me add that it is almost as bad for the writer, who is obliged to hasten hither and thither, and, like a huntsman with a struggling pack, to urge on the tardy, correct the loiterer, and repress the eager. (II 25)

As this image suggests, the story could potentially swirl in all sorts of directions: the proliferation of scenes and episodes is such that exerting a measure of narrative control becomes arduous work. Readers are solicited to contemplate not one main direction for the story that unfolds, but several potential lines of development, a variety of narrative futures in which to invest their attention. Who among the minor accomplices that surround Grog will play a decisive role? Count Lienstahl, Paul Classon, or Lazarus Stein? All of them are presented in elaborate cameos that induce readers to anticipate their relevance for the story, their future value, though only Classon will be truly instrumental in furthering Grog's plans. In a novel that invests so much in variety - in terms of geographical settings, creation of characters, narrative styles, adventures and incidents - readers find themselves in the position of investors whose portfolio includes a vast array of futures that may or may not pay off.

A clearer sense of directionality and even predictability, on the other hand, colours the speculation plot. As the Examiner observed, reviewing the first instalment of the novel, "we reach the middle of the tale, and with it the pinnacle of Mr Dunn's good fortune, from which we are already looking down at the first steps of his descent" ("Davenport Dunn" 288). In contrast to foreign settings, Ireland appears as the land of narrative certainties: the outcome of Dunn's story is a foregone conclusion; descent is inevitable. Much as Lever enjoys portraying this speculator as a character with unique features, the overall structure of his career is predetermined in advance, as the monthly public, accustomed to reading about financial scandals in the periodical press and in fiction, would no doubt have known. This strand of the novel reserves fewer surprises and encourages fewer speculations. Of course the details of how Dunn rises and falls allow for some degree of anticipation. And Sybella's interventions are a surprising novelty. But the narrative arc is remarkably stable; the narrator does not hasten hither and thither with apologies and asides in order to orient the dazzled reader, and the ratio of minor to major characters is much smaller. In other words, on the formal level, speculation is assimilated to order, the rationality of narrative control, and reliable predictions about future developments. Grog's activities, on the other hand, are couched in a narrative mode that capitalises on the exuberant proliferation of narrative bubbles: episodes, dialogues, scenes, and vignettes that offer imaginative possibilities in which readers may or may not invest.

Through the continuous alternation of these two narrative modes the novel articulates a complex vision of speculation in relation to gambling. That there are significant analogies between the two is not denied: Dunn himself insists on them when warning Lady Lackington against the false promises of facile profits to be gained by "some wonderful speculation" which, he claims, would be "very like gambling" (I 112). However, the novel reconfigures the relation between gambling and speculation in such a way as to displace onto the former associations with uncertainty, the creation of bubbles and fictionality, thus allowing the latter to appear purged of the most irrational elements and integrated within a discourse of rational calculation and narrative order. The similes Lever uses to describe the two co-protagonists further re-enforce these connotations. Dunn is likened to a "geographer", for instance, who designs the route "by which the explorer is to journey through a desert" (I 88) or to a "physician" who listens to the harrowing tales of his patients: "what the doctor was to the world of sickness and infirmity did [Dunn] become to the world of human passions and 
desires" (I 89). And just as doctors read symptoms and use their knowledge to devise a cure, so too the speculator is presented as a clinical observer who, "by a patient study of men themselves", devises strategies for enrichment based on the certainty that "every man, whatever his station, covets wealth" (I 88). This comparison, of course, is also meant to highlight the "moral rottenness" of a society bent on coveting wealth (I 90). But the emphasis on study, observation and a quasi-scientific understanding of human motives places Dunn in the same category as other practitioners of science whose deductions result from years of learning. Similarly, the command he exerts over the "immense fortress" of his financial empire is likened to the abilities of military strategists: "To have ever a force ready on the point assailed was Dunn's remarkable talent, and he handled his masses like a great master of war" (I 430). Whether as a geographer, a physician or a master of war, the speculator is insistently related to figures of rationality.

An altogether different string of images characterizes Grog Davies, all linked by the common denominator of artistry and fictionality. He is described as a "great artist" (I 303) capable of weaving fictitious tales that never fail to hit their mark:

The glorious picture of a race-course, with its attendant rogueries, betting-stands clammed with 'flats', a ring crowded with 'green-horns', was a tableau of which he never wearied. Now, this was the sort of landscape Grog touched off neatly. All the figures he introduced were life-studies, every tint and shade and effect taken carefully from nature. With a masterly had he sketched out a sort of future campaign, artfully throwing Beecher himself into the foreground, and making him fancy that he was in some sort necessary to the great events before them. (I 303)

Consummate in the art of creating illusions, endowed with "all the marvelous power of a good story-teller" (II, 118) and possessing the "considerable talents" of a stage performer, Grog uses every tool in his box to produce fictions that dupe both friends and enemies. In the eyes of his friend and victim, Beecher, Grog is alternatively a "Michael Angelo" to be venerated and a grand, mystifying painting waiting to be deciphered. Lever compares him to Turner's later works, "one of those strange, incomprehensible creations, where cloud and sea, atmosphere, shadow, and smoke, seem madly commingled with tall masts piercing the lurid vapor, and storm-clouds drifting across ruined towers" (I 127-28). Fictionality is decidedly on the side of gambling in this novel. Compared to the supreme artistry of Grog, Dunn's ability to form new companies, raise money and use financial knowledge to his own advantage appears as a more mundane, down-to-earth type of endeavor. Both characters are accomplished schemers, but the different chains of metaphors deployed to describe their actions effectively displace fictionality and the art of creating airy nothings within the symbolic realm of gambling, while attributing to speculation an affinity with science.

\section{Conclusion}

The various features analysed in the previous section - the geographical distribution of episodes, the alternation of picaresque and realist narrative modes, and the connotations introduced via metaphorical patterns - carry special significance in relation to a broader set of discourses about the seductive appeal of speculation at mid-century and the cultural status of investment practices that appeared to many indistinguishable from gambling. Historians and sociologists agree that the legal, cultural and political struggles through which financial markets gained increased legitimacy over the course of the nineteenth century entailed a continuous attempt to separate speculative trading from gambling. As David Itzkowitz has argued, "drawing the line between gambling and other forms of financial risk had particular 
urgency during the Victorian period" (5). According to de Goede, "it was only through creating a contrast with gambling that finance was able to emerge as a respectable element out of early modern networks of monetary activity" (50). For Urs Stähli, detaching speculation from gambling was a crucial strategy in order to show that "the financial system was capable of policing its own boundaries" (43).

Davenport Dunn can be viewed as one further contribution to these debates. The novel accords a degree of legitimacy to financial speculation by multiplying lines of separation (geographical, formal and metaphoric) and by imagining a connection between finance and social progress that pivots on the actions and aspirations of a female character whose destiny is changed by her involvement in speculative enterprises. Thus, the novel contributes to reconfiguring the cultural status of finance capitalism even as it replicates the moralising antispeculation discourse that was so widespread in British financial print culture in the wake of the 1840 s Railway mania. ${ }^{17}$ While it is certainly true, as Tamara Wagner claims, that the majority of Victorian writers "remained suspicious of both the speculative economy and the economic theories supporting it" (9), creating "some of the most satirical exposures of risk management" (9), it is debatable whether suspicion and satire were the only literary responses to the rise of finance capitalism in the middle decades of the nineteenth century. Davenport Dunn shows that imaginative engagement with the speculative economy could take many forms, including the exploration of narrative paths that extol the advantages of speculation, as Lever does by shifting attention to the role of a female character who stands to win from her commitment to speculative schemes. The novel registers anxieties about the indeterminacy of values ushered in by finance capitalism, and, at the same time, offers reassurances that prices and future values are determined by rational assessments and calculations; likewise, while the speculator and the gambler are both of questionable morality, Lever invests substantial creative energy in imagining lines of distinction. In its very structure Davenport Dunn tells a story of differentiation that safeguards speculation from the excess, disorder, extravagant exuberance displaced onto the sphere of gambling.

This composite set of ideological perspectives becomes more discernible through a formalist reading that calls attention to recurrent patterns and features. Mary Poovey has argued that in the vast majority of British fiction, published between the late 1840s and the end of the century, financial plots are "thematically central but formally marginal elements of a narrative system that creates a formal consensus among the novel's variety of events and characters" (37). In Davenport Dunn, however, the financial plot enjoys a high degree of centrality both thematically and formally. As my analyses show, it is mostly at level of form that the novel reproduces the logic of financial speculation. At mid-century this logic entailed, first of all, drawing distinctions between speculation and gambling as well as between productive investments and fraudulent schemes. In broader terms, speculation also entails placing value in futurity; as Claire La Berge explains, "to finance is to have a narrative about how the future will unfold" (28). Davenport Dunn projects two narratives about the future: one in which fairly predictable outcomes and an orderly trajectory prevail (Dunn's schemes are bound to fail), and another one in which dilatory strategies allow for the exuberant cropping up of narrative bubbles that invite conjectures about less predictable futures. As Victorian reviewers rightly intuited, Lever was less interested in confirming the standardised tale of financial felony than he was in exploring the allure of speculation, understanding its mechanisms and imagining narrative situations in which its default negativity is suspended. Usually dismissed as a peripheral contribution to the emerging sub-genre of financial writing, Davenport Dunn is a nuanced exploration of the allure and impact of speculation, which places Ireland (rather than London) at the very centre of the financial plot and reserves a nonmarginal role to the agency of a female risk-taker. Applying to non-canonical novels the same kind of close reading usually reserved to 'elite' works, with their consolidated pedigree of 
sophistication, can broaden our understanding of how the development of finance capitalism was refracted in the prism of literature and how literature helped normalise the operations of finance.

\section{Notes}

1 Reviewers also appreciated Lever's turn in the direction of serious realism. Soon after his death, the Blackwood's Edinburgh Magazine (to which Lever had contributed from 1863 to 1872) published an extended article celebrating the novelist and his works. Rather than his comic vein, the article praised Lever's "insight into human character ...In describing this as his greatest gift, we are probably not expressing a popular opinion. Thousands of his readers read him merely for his fun - simply that they may laugh - and pay little attention to any other characteristic. But in this they made the same sort of mistake which people commit who, in drinking champagne, value it only for its sparkle and effervescence, and are blinded by this accident of the wine, to the merit of its essential quality' ("Charles James Lever" 333). Lever himself believed that "real success" could be reaped by expanding his narrative scope beyond the gaiety of comic adventures (see Downey 352).

${ }^{2}$ More puzzling still is Norman Russell's choice to discuss, however briefly, Lever's novel The Bramleighs of Bishop's Folly in his fairly comprehensive account of literary responses to commercial and financial modernity (The Novelist and Mammon, 1986), while ignoring Davenport Dunn.

${ }^{3}$ As Alex Preda writes, "from the mid nineteenth-century on boundaries were set, which by the dawn of the twentieth century were able to contain criticism, doubts and ethical questions... These boundaries could be seen as a relentless process of rationalization ... which makes financial markets more and more rational" (Pread 2223).

${ }^{4}$ The Irish banker, John Sadleir, was arguably a source of inspiration for Lever in the creation of Dunn. Sadleir's astonishing rise to power and wealth is fully documented by James O'Shea.

${ }^{5}$ As Joe Cleary explains "Irish modernity has ... in one way and another come to seem to many as puzzlingly eccentric and strange; its history enigmatically at odds with standard vectors of modernisation that Western European core countries apparently exemplify." Histories and sociologies of Irish modernity, he continues, "frequently turned into extended deliberations on Ireland's deficient modernisation" (10). Lever's take on the process of modernisation, in this novel, hinges on the contrast between a new economic climate and a traditional social template resistant to change.

${ }^{6}$ On the centrality of the figure of the outsider in Lever's novels see Bareham (96).

${ }^{7}$ Merdle in Little Dorrit, is one prime example of a fictional financier shrouded in mystery: his business dealings are never detailed. Later on in the century, Trollope will have recourse to the same narrative strategy in his depiction of Ferdinand Lopez (a foreigner about whose family nothing is known), in The Prime Minister (1876) and of Melmotte, in The Way We Live Now, whose whereabouts, before moving to London, remain a matter of some speculation throughout the novel.

${ }^{8}$ In Michie's interpretation, Dunn's story articulates a dual vision of finance as both progressive and "wasteful" (40).

${ }^{9}$ The Blackwood's Edinburgh Magazine described Sybella as "painfully intellectual", "equally great in finance, political economy, and landscape-gardening" ("Charles James Lever" 338); she appeared a tad too extreme for the conservative tastes of Maga's readers.

${ }^{10}$ In Lever's realistic rendering of the speculation plot, even the story of how Dunn comes to discover that Sybella is in possession of sound economic knowledge is considered worthy of being detailed: "It is about two months back a little volume came into my hands" Dunn tells Sybella, "it was a work on the industrial resources of Ireland, annotated an commented on by you. I have it still. Shall I own to you that your notes have been already used by me in my reports, and that I have adopted some of the suggestions in my recommendations to Government" (I 290). This is just one example of the level of particularity the novel reaches when dealing with a topic that most of Lever's fellow authors were content to represent in vague terms.

11 "The boundaries of finance set in place in the nineteenth century...include a kaleidoscope of rational and irrational elements...In this kaleidoscope, notions that speculation is not different from a commercial transaction, that the stock exchange fulfils specific economic functions, are mixed with those of the social organism powered by the vital force of speculation, participating in the community not by virtue of equal rights but by virtue of sharing in this force" (Preda 194).

${ }^{12}$ The butt of Lever's sarcasm is the attractiveness of speculative schemes endorsed by the aristocracy: "Amongst the many advantages fortune bestowed upon the grand Glengariff scheme was conspicuously one Dukes had approved, and Earls admired it...where is the born Briton would not feel the air balmier and the 
breeze more zephyr-like if he could see that it waved a royal standard? Where the Anglo-Saxon who would not think the seas more salubrious that helped to salt a duke?" (II 151-52).

${ }^{13}$ In mid-Victorian financial print culture, vulnerable "widows" with some money to invest are often singled out as the innocent victims ruined by speculation and the false promises of company prospectuses. See for example the article "How the Bank was Wound up" published in All Year Round in 1865: "One poor lady-the widow of a clergyman - had been induced into taking shares, upon which she had paid five hundred pounds - the half of all she had in the world - and was now liable for at least five times that amount. She had thus utterly ruined herself, and with her were ruined four children under ten years of age" (Meason 277). In Lever's novel, aristocratic ladies have a marked interest in buying shares, from which they expect exceptionally high returns (I 22). On the role of women investors in nineteenth-century Britain see Henry, Green and Owens, Maltby and Rutterford, and Beachy et al.

${ }^{14}$ It is worth mentioning that Lever, as McCourt reminds us, "spent the greater part of his adult life 'dislocated' in Europe, always negotiating between 'home' and 'away', between 'here' (mostly Dublin), and a sprawling, variegated European 'elsewhere"” (149). It is through a European lens, McCourt argues, that "Lever's Ireland was brought into focus" (154).

${ }^{15}$ On these debates see Itzkowitz, De Goede, Stähli, Flavin and Franklin.

16 The Blackwood's Edinburgh Magazine described Lever's penchant for the anecdotal as "illegitimate excursions": "the thread of the story is continuously interrupted by malapropos anecdotes; our sympathy with the hero and our interest in the plot are brusquely arrested, and, for long chapters, we have to follow some casual racounteur who changes the venue of our interest... his stories are often too much overlaid with incidents...He is encumbered by the wealth of his fancy. He lavishes on one chapter the material for a book, and on one book the material for a whole library of fiction; and we, too, embarrassed by this profusion, sometimes feel half inclined to give up the plot in despair - to divert, by a conscious effort, our interest from the final issue, and devote ourselves to the separate enjoyment of each episode as it presents itself'( 'Charles James Lever 344).

${ }^{17}$ The Railway Mania of 1845-46 was an instance of speculative frenzy in Britain, which proved disastrous for most investors in railway common shares and soon came to be regarded as a notorious example of fraudulent finance: "The Railway Mania in all its excess exemplified the new scale of industrial finance and the new kinds of fraud which were to plague the modern English economy" (Robb 55).

\section{Works Cited}

Bareham, Tony, ed. Charles Lever: New Evaluations. Savage: Barnes \& Noble, 1991. . "Charles Lever and the Outsider". Charles Lever: New Evaluations. Ed. Bareham Tony. Savage: Barnes \& Noble, 1991. 96-122.

Beachy, Robert, Béatrice Craig and Alastair Owens, eds. Women, Business and Finance in Nineteenth-Century Europe: Rethinking Separate Spheres. Oxford: Berg, 2006.

“Charles James Lever”. Blackwood's Edinburgh Magazine. 112. 683 (1872): 327-360.

Cleary, Joe. "Introduction: Ireland and Modernity". The Cambridge Companion to Modern Irish Culture. Eds. Joe Cleary and Claire Connolly. Cambridge: Cambridge University Press, 2005. 1-21.

"Davenport Dunn". The Examiner, 10 April 1858: 228.

"Davenport Dunn". The Saturday Review 7.182 (1859): 505-6.

Downey, Edmund. Charles Lever: His Life in His Letters. 2 vols. Edinburgh: Blackwood and Sons, 1906.

Flavin, Michael. Gambling in the Nineteenth-Century English Novel: "A Leprosy is o'er the Land”. Brighton: Sussex Academic Press, 2003.

Franklin, J. Jeffrey. Serious Play: The Cultural Form of the Nineteenth-Century Realist Novel. Philadelphia: University of Pennsylvania Press, 1999.

Goede, Marieke de. Virtue, Fortune and Faith: A Genealogy of Finance. Minneapolis: University of Minnesota Press, 2005.

Green, David R., and Alastair Owens. "Gentlewomanly Capitalism? Spinsters, Widows, and Wealth Holding in England and Wales, c.1800-1860". Economic History Review 56. 4 (2003): 510-36. 
Green, David R., Alastair Owen, Josephine Maltby and Janette Rutterford, eds. Men, Women, and Money: Perspectives on Gender, Wealth, and Investment 1850-1930. Oxford: Oxford University Press, 2011.

Haddelsey, Stephen. Charles Lever: The Lost Victorian. Gerrard Cross: Colin Smythe, 2000.

Hand, Derek. A History of the Irish Novel. Cambridge: Cambridge University Press, 2011.

Henry, Nancy. "'Ladies do it?':Victorian Women Investors in Fact and Fiction". Victorian Literature and Finance. Ed. Francis O'Gorman. Oxford: Oxford University Press, 2007. 111-34.

Itzkowitz, David C. "Fair Enterprise or Extravagant Speculation: Investment, Speculation, and Gambling in Victorian England". Victorian Studies 45.1 (2002): 121-147.

Kelly, James, ed. The Cambridge History of Ireland. Volume III 1730-1880I. Cambridge: Cambridge University Press, 2018.

La Berge, Leigh Claire. Scandals and Abstraction: Financial Fiction in the Long 1980s. Oxford: Oxford University Press, 2015.

Lever, Charles. Davenport Dunn: A Man of Our Day. 2 vols. Boston: Little, Brown, and Company, 1902.

McCourt, John. "Charles Lever: An Irish Writer in Italy". Studi irlandesi. A Journal of Irish Studies 6 (2016): 149-169.

Meason, Malcolm Ronald Laing. "How the Bank was Wound Up". All Year Round 13.312 (1865): 276-282.

Michie, Ranald. Guilty Money: The City of London in Victorian and Edwardian Culture, 1815-1914. London: Pickering \& Chatto, 2009.

Murphy, James H. Irish Novelists and the Victorian Age. Oxford: Oxford University Press, 2011.

O'Shea, James. Prince of Swindlers. John Sadleir M.P. 1813-1856. Dublin: Geography Publications, 1999.

Poovey, Mary. "Writing about Finance in Victorian England: Disclosure and Secrecy in the Culture of Investment". Victorian Studies 45.1 (2002): 17-41.

Preda, Alex. Framing Finance. The Boundaries of Markets and Modern Capitalism. Chicago: The University of Chicago Press, 2008.

Reed, John. "A Friend to Mammon: Speculation in Victorian Literature". Victorian Studies 27. 2 (1984): 179-202.

Robb, George. White-Collar Crime in Modern England: Financial Fraud and Business Morality, 1845-1929. Cambridge: Cambridge University Press, 1992.

Robbins, Bruce. Upward Mobility and the Common Good: Toward a Literary History of the Welfare State. Princeton: Princeton University Press, 2007.

Russell, Norman. The Novelist and Mammon: Literary Responses to the World of Commerce in the Nineteenth Century. Oxford: Clarendon Press, 1986.

Stähli, Urs. Spectacular Speculation: Thrills, the Economy and Popular Discourse. Stanford: Stanford University Press, 2013.

Wagner, Peter. Progress: A Reconstruction. Cambridge: Polity Press, 2016.

Wagner, Tamara. Financial Speculation in Victorian Fiction. Plotting Money and the Novel Genre, 1815-1901. Columbus: The Ohio State University Press, 2010.

Received: 16 September $2018 \quad$ Final version accepted: 21 January 2018 
Silvana Colella is Professor of English at the University of Macerata, in central Italy, and Senior Research Fellow at Coventry University. Her primary scholarly work focuses on nineteenth century British literature and culture. She has published books and articles on women writers, gender and feminist theories, and the interconnections between literature and economic thought. More recently her research interests have expanded to include cultural heritage as an area of critical inquiry. In 2016, she was appointed President of the European Consortium of Humanities Institutes and Centres (ECHIC).

silvana.colella@unimc.it 